\title{
Assessing extracellular enzymatic activity in the soil on addition of root biomass with different biochemical composition
}

\author{
Sandeep Sharma ${ }^{1}$, Neha Sharma ${ }^{1,2, *}$ and Neemisha ${ }^{1}$ \\ ${ }^{1}$ Department of Soil Science, and \\ ${ }^{2}$ Department of Microbiology, Punjab Agricultural University, Ludhiana 141 004, India
}

Biochemical quality of a biomass determines the rate of its decomposition, which ultimately affects the relative microbial communities. Root biomass constitutes a significant fraction of total plant biomass and can play an important role in affecting microbial activity and extracellular soil enzymes when roots have different biochemical composition. To address the pivotal action of biochemical quality, a short-term incubation study was carried out to determine the effect of heterogeneity of root biomass on the functional characteristics of enzyme activities in the soil. Root biomasses of six crops with contrasting chemical composition (Oryza sativa, Zea mays, Gossypium hirsutum, Glycine max, Cajanus cajan and Sesamum indicum) were applied alone as well as in different combinations to a sandy-loam soil incubated under controlled environment condition for 63 days. The enzyme activity peaked on the 42nd day, which ranged from 11.85 to $16.85 \mu \mathrm{g}$ triphenylformazan and from 9.84 to $13.67 \mu \mathrm{g}$ p-nitrophenol $\mathrm{g}^{-1} \mathbf{h}^{-1}$ for dehydrogenase and alkaline phosphatase respectively. Among the different root biomasses and their combinations, maximum soil enzyme activity was found for $Z$. mays (T2) followed by $G$. $\max (\mathrm{T} 4)$ and $G$. $\max +O$. sativa (T9). The roots of Oryza sativa (T3), Cajanus cajan (T6) and Cajanus cajan + Oryza sativa (T10) with high contents of hemicellulose and low contents of cellulose showed low enzymatic activity. Cellulose and hemicellulose contents in root biomass are mainly responsible for the enhanced functional diversity of soil microbial communities as well as enzyme activities.

Keywords: Biochemical composition, enzymatic activity, root biomass, soil microbial communities.

THE decomposition of plant residues in soils is not only regulated by environmental factors, but also by their biochemical composition ${ }^{1,2}$. Therefore, the residue heterogeneity helps in stimulating various microbial communities which significantly affect the extracellular soil enzymes ${ }^{3}$. However, the decomposition of plant residues has been much better studied for above- ground than for below-ground components ${ }^{4}$.

\footnotetext{
*For correspondence. (e-mail: neha-mb@pau.edu)
}

Root biomass and C-rich bio-macromolecules (celluloses, hemicelluloses) facilitate the synthesis of extracellular enzymes in the rhizosphere by accelerating the microbial population ${ }^{5-7}$. The quantity of root residue returned to the soil influences the soil organic matter content, but biochemical heterogeneity and soil enzymes among residues become important when other factors are kept constant.

Currently, soil enzymes are considered as 'sensors' of soil quality since they are relatively simple to measure, sensitive to environmental stress and respond rapidly to changes in the microbial status and physico-chemical conditions in the soil ${ }^{8,9}$. Extracellular enzyme activities can also be directly affected by factors such as temperature, moisture, $\mathrm{pH}$, nutrient availability and biochemical properties of the litter or root biomass ${ }^{9,10}$.

Despite the huge amount of experimental work on residue decomposition in the soil, little is known about the impacts on the heterogeneity of root biomass, i.e. effect of incorporated biomass having different compositions on the dynamics of enzyme activities. The present study, therefore, was undertaken to relate the broad range of biochemical compositions of root biomass of annual crops to soil enzyme activities and $\mathrm{C}$-mineralization rate in a sandy-loam soil under laboratory conditions. The novelty of the present study is to estimate the impact of biochemically differential root biomass composition of annual crops on soil enzymes for identification of probable indicators.

\section{Materials and methods}

\section{Experimental set-up}

This study was undertaken in the laboratory of the Department of Soil Science, Punjab Agricultural University (PAU), Ludhiana, India. The soil used in the study was of Typic Ustipsamment type, collected from the experimental farm of PAU $\left(30^{\circ} 56^{\prime} \mathrm{N}, 75^{\circ} 52^{\prime} \mathrm{E}\right)$ in the Indo-Gangetic plains of northwestern India. Sampling was done from eight soil cores $(0-0.15 \mathrm{~m})$, homogenized, partially air-dried, ground and sieved $(<2 \mathrm{~mm}$ mesh) to make a composite sample of approximately $50 \mathrm{~kg}$. Table 1 
shows the physical and chemical characteristics of the sampled soil.

Six representative plants species (main crops or cover crops) of agricultural systems in India, including two Poaceae (maize, rice), two Fabaceae (soybean, pigeonpea), one Malvaceae (cotton) and one Pedaliaceae (sesame) were selected for the study (Table 2). The root biomass was sampled using the excavation method, separated manually, dried and cut into $1 \mathrm{~cm}$ length for the study at the start of senescence during the growing season for the root system mass. A sub-sample of each was also dried at $60^{\circ} \mathrm{C}$, ground and used for chemical analysis (macro- and micro-nutrients; determined using ICAP elemental analysis) (Table 3). Cellulose and hemicellulose contents were estimated by proximate analysis using neutral digestion method ${ }^{11}$.

The experiment was laid out in a completely randomized design with three replicates per treatment. The roots were added at the rate equivalent to $1.0 \%$ (except control), either alone or in a combination of $1: 1(\mathrm{w} / \mathrm{w}$ dry-weight basis) in polypropylene pots containing $400 \mathrm{~g}$ soil. The 11 treatments consisted of an unamended soil (control) and different root biomasses either used alone or in combinations (Table 2). The base of the pot was tapped firmly to allow the contents to settle, moistened to field capacity $(20 \% \mathrm{w} / \mathrm{w})$ and maintained in a moist aircirculating chamber at $30^{\circ} \mathrm{C}$ throughout the 63-day duration of the experiment.

\section{Measurement of soil enzymatic activities and $C$ mineralization}

Soil sampling was done from the treatments at time intervals of $1,3,7,14,21,28,42$ and 63 days after incubation (DAI), and stored at $4{ }^{\circ} \mathrm{C}$ immediately for subsequent

Table 1. Initial physico-chemical characteristics of the experimental soil

\begin{tabular}{lc}
\hline Parameters & Value \\
\hline $\mathrm{pH}$ & 7.6 \\
$\mathrm{EC}\left(\mathrm{dS}^{-1}\right)$ & 0.28 \\
$\mathrm{OC}\left(\mathrm{g} \mathrm{kg}^{-1}\right)$ & 4.2 \\
Available N $\left(\mathrm{kg} \mathrm{ha}^{-1}\right)$ & 87.2 \\
Available P $\left(\mathrm{kg} \mathrm{ha}^{-1}\right)$ & 12.2 \\
Available K $\left(\mathrm{kg} \mathrm{ha}^{-1}\right)$ & 84 \\
Sand $(\%)$ & 64.4 \\
Silt $(\%)$ & 24.3 \\
Clay $(\%)$ & 11.3 \\
Texture & Sandy loam \\
Zinc (ppm) & 1.40 \\
Copper (ppm) & 0.94 \\
Iron (ppm) & 4.20 \\
Manganese (ppm) & 3.33 \\
\hline
\end{tabular}

*pH, water: soil :: $2: 1$; EC, Electrical conductivity; OC, Organic carbon; $\mathrm{N}, \mathrm{KMNO}_{4}$ oxidizable nitrogen; $\mathrm{P}$, Olsen phosphorus; K, Ammonium acetate exchangeable potassium. analysis of enzyme activity (dehydrogenase (DHA), alkaline phosphatase (ALP), basal soil respiration (BSR)) to avoid minimum loss after collection.

DHA activity was determined using the method of Camina et al. ${ }^{12}$. DHA was quantified from $1 \mathrm{~g}$ of soil sample using $0.2 \mathrm{ml}$ of $3 \%$ triphenyltetrazolium chloride (TTC) and $0.5 \mathrm{ml}$ of $1 \%$ glucose solution and incubated at $30^{\circ} \mathrm{C}$ for $24 \mathrm{~h}$. Next, the triphenyl foramazan (TPF) produced was extracted with $10 \mathrm{ml}$ ethanol and determined spectrophotometrically $(485 \mathrm{~nm})$ after $2 \mathrm{~h}$ of refrigeration. Each DHA activity measured was the mean of three replicates, and expressed as $\mu \mathrm{g}$ TPF $\mathrm{g}^{-1} \mathrm{~h}^{-1}$.

ALP was assayed on the basis of $p$-nitrophenol (PNP) release after the cleavage of $p$-nitrophenyl phosphate (PNPP) by alkaline phosphomonoesterase. Briefly, ALP activity was measured in $1 \mathrm{~g}$ air-dried soil sample incubated in $0.2 \mathrm{ml}$ toluene, $4 \mathrm{ml}$ modified universal buffer (MUB, $\mathrm{pH}=11$ ) and $1 \mathrm{ml}$ of $0.05 \mathrm{M}$ PNPP solution at $37^{\circ} \mathrm{C}$ for $1 \mathrm{~h}$. The addition of $1 \mathrm{ml}$ of $0.5 \mathrm{M} \mathrm{CaCl}_{2}$ and $4 \mathrm{ml}$ of $0.5 \mathrm{M} \mathrm{NaOH}$ helped stop the reaction. Finally, the soil suspension was filtered and the filtrate was analysed for the estimation of PNP content on a spectrophotometer at $420 \mathrm{~nm}$ (ref. 13). The activity of alkaline phosphomonoesterase was expressed as $\mu \mathrm{g}$ PNP $\mathrm{g}^{-1} \mathrm{~h}^{-1}$.

BSR of the samples was determined by trapping the evolved $\mathrm{CO}_{2}$ in $\mathrm{NaOH}$ and the unreacted alkali in the $\mathrm{CO}_{2}$ traps was then back-titrated with $1 \mathrm{~N} \mathrm{HCl}^{14}$. The $\mathrm{CO}_{2}$ absorbed in the traps was titrated at 1, 3, 7, 14, 21, 28, 42 and 63 days of $\mathrm{NaOH}$ placement. In this method, $\mathrm{CO}_{2}$ evolved from each sample was calculated as the difference between the initial $\mathrm{CO}_{2}$ concentration and that after each measurement period. BSR was calculated based on cumulative $\mathrm{CO}_{2}$ evolution over a 30 day period.

Soil organic carbon (SOC) was analysed by the Walkley-Black chromic acid wet oxidation method ${ }^{15}$ using a diphenylamine indicator. SOC content after oxidation was determined by titration of the excess potassium dichromate using a $0.1 \mathrm{M}$ solution of Mohr's salt.

\section{Statistical analysis}

All the data were analysed using analysis of variance (ANOVA) with IRRISTAT version 5.0. Least significance difference (LSD) at 0.05 level of probability was used to test the significance of differences among treatment means. Relationships between the measured parameters, DHA, ALP, BSR, organic carbon (OC) among different root biomasses and the combination of different species were determined by means of correlation tests (Pearson correlation coefficients), and significance was compared at a level of probability $(P)$ of $<0.05^{* *}$ and $<0.01^{*}$.

\section{Results and discussion}

Figure 1 shows the chemical compositions of different root biomasses used in the study, which were analysed to 
Table 2. Treatments used in the study and the respective crop descriptions

\begin{tabular}{|c|c|c|c|}
\hline Treatment & Latin name & English name & Family \\
\hline T0 & - & Control & - \\
\hline $\mathrm{T} 1$ & Gossypium hirsutum & Cotton & Malvaceae \\
\hline $\mathrm{T} 2$ & Zea mays & Maize & Poaceae \\
\hline T3 & Oryza sativa & Rice & Poaceae \\
\hline $\mathrm{T} 4$ & Glycine $\max$ & Soyabean & Fabaceae \\
\hline T5 & Sesamum indicum & Sesame & Pedaliaceae \\
\hline T6 & Cajanus cajan & Pigeon pea & Fabaceae \\
\hline $\mathrm{T} 7(=\mathrm{T} 1+\mathrm{T} 2)$ & G. hirsutum $+Z$. mays & Cotton + maize & Malvaceae + Poaceae \\
\hline $\mathrm{T} 8(=\mathrm{T} 2+\mathrm{T} 3)$ & Z. mays $+O$. sativa & Maize + rice & Poaceae + Poaceae \\
\hline $\mathrm{T} 9(=\mathrm{T} 3+\mathrm{T} 4)$ & G. $\max +O$. sativa & Soyabean + rice & Fabaceae + Poaceae \\
\hline $\mathrm{T} 10(=\mathrm{T} 3+\mathrm{T} 6)$ & C. cajan $+O$. sativa & Pigeonpea + rice & Fabaceae + Poaceae \\
\hline $\mathrm{T} 11(=\mathrm{T} 3+\mathrm{T} 5)$ & $S$. indicum $+O$. sativa & Sesame + rice & Pedaliaceae + Poaceae \\
\hline
\end{tabular}

Table 3. Analysis of macro- and micro-nutrient concentrations in different treatments of root biomass

\begin{tabular}{lccccccc}
\hline Root biomass & $\mathrm{Zn}(\mathrm{ppm})$ & $\mathrm{Fe}(\mathrm{ppm})$ & $\mathrm{Mn}(\mathrm{ppm})$ & $\mathrm{Cu}(\mathrm{ppm})$ & $\mathrm{N}(\%)$ & $\mathrm{P}(\%)$ & $\mathrm{K}(\%)$ \\
\hline G. hirsutum & 23.9 & 639 & 18.0 & 6.3 & 0.29 & 0.035 & 0.63 \\
Z. mays & 25.6 & 1285 & 28.0 & 7.8 & 0.33 & 0.037 & 0.83 \\
O. sativa & 145 & 4547 & 127 & 19.8 & 0.66 & 0.031 & 1.06 \\
G. max & 10.3 & 437 & 16.2 & 8.0 & 0.31 & 0.011 & 0.21 \\
S. indicum & 19.3 & 479 & 14.1 & 6.8 & 0.26 & 0.045 & 1.53 \\
C. cajan & 17.1 & 400 & 12.2 & 6.3 & 0.46 & 0.027 & 0.55 \\
G. hirsutum + Z. mays & 23.0 & 938 & 24.4 & 6.1 & 0.50 & 0.044 & 0.78 \\
O. sativa + Z. mays & 109 & 3165 & 97.7 & 34.1 & 0.47 & 0.037 & 0.96 \\
G. max + O. sativa & 118 & 2358 & 79.0 & 12.7 & 0.46 & 0.029 & 0.68 \\
C. cajan + O. sativa & 99.0 & 3091 & 77.1 & 9.4 & 0.61 & 0.035 & 0.80 \\
S. indicum + O. sativa & 101 & 2069 & 64.5 & 11.0 & 0.46 & 0.045 & 1.42 \\
\hline
\end{tabular}

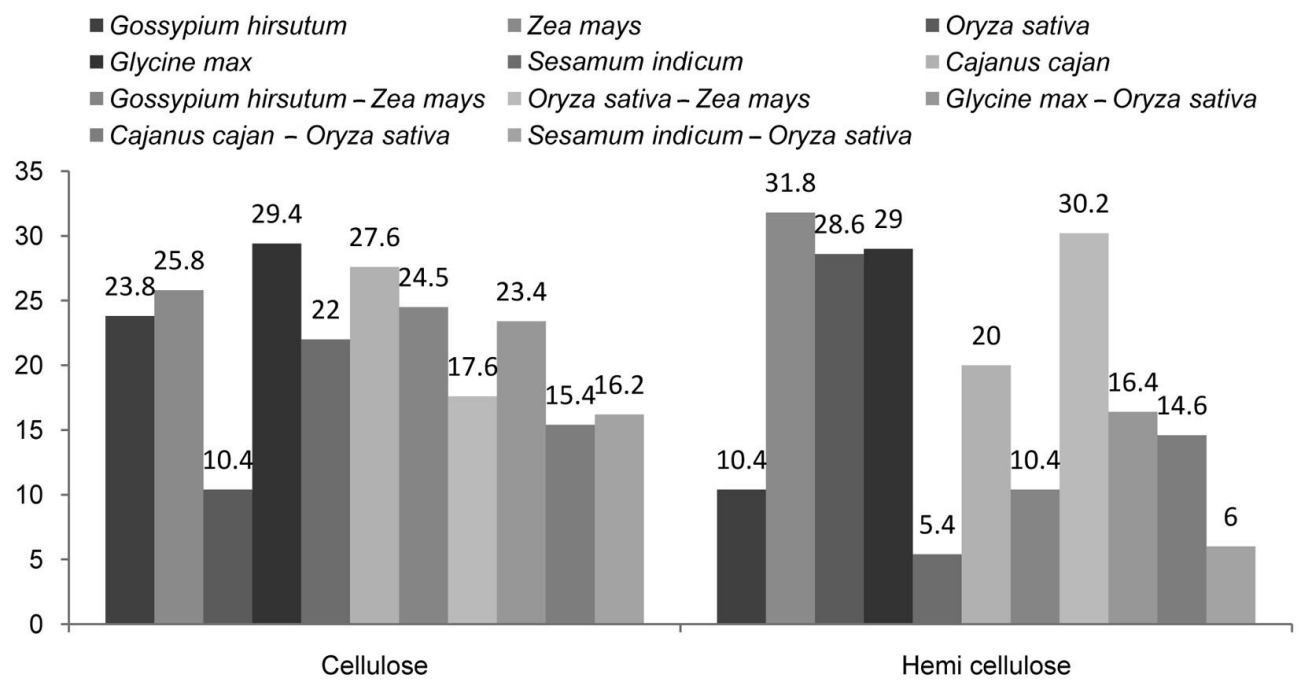

Figure 1. Cellulose and hemicellulose content (\%) in different root biomasses.

identify the most significant differences among the species. The cellulose content of root residues ranged from $10.4 \mathrm{~g} \mathrm{~kg}^{-1}$ for rice to $29.4 \mathrm{~g} \mathrm{~kg}^{-1}$ for soybean, and hemicellulose content ranged from $5.4 \mathrm{~g} \mathrm{~kg}^{-1}$ for sesamum to $31.4 \mathrm{~g} \mathrm{~kg}^{-1}$ for maize (Figure 1). The roots of Poaceae exhibited high variability in their chemical composition when compared to those of species of other families which are all dicotyledons (Malvaceae, Fabaceae, Pedaliaceae). Conversely, the proportion of hemicellulose in Poaceae was higher than for other species, and the differences in composition among the roots of Poaceae species were lower. Results of the present study confirm our 
Table 4. Changes in dehydrogenase ( $\mu \mathrm{g} \mathrm{TPF} \mathrm{g}^{-1}$ soil $\mathrm{h}^{-1}$ ) activity among different root biomass treatments at various days of incubation

\begin{tabular}{|c|c|c|c|c|c|c|c|c|}
\hline & $1 \mathrm{st}$ & $3 \mathrm{rd}$ & 7 th & 14 th & 21 th & 28 th & 42 th & 63 th \\
\hline Control & 2.51 & 4.22 & 8.05 & 6.45 & 6.98 & 4.61 & 7.59 & 8.15 \\
\hline G. hirsutum & 3.49 & 4.31 & 8.74 & 8.11 & 10.31 & 3.68 & 11.85 & 8.72 \\
\hline Z. mays & 3.85 & 4.01 & 10.36 & 9.56 & 10.55 & 5.03 & 13.77 & 11.60 \\
\hline O. sativa & 5.36 & 5.90 & 9.09 & 7.50 & 9.91 & 4.13 & 12.62 & 9.59 \\
\hline G. $\max$ & 3.86 & 4.71 & 9.24 & 7.19 & 10.66 & 5.03 & 14.35 & 10.82 \\
\hline S. indicum & 4.28 & 4.87 & 8.98 & 7.44 & 7.31 & 4.78 & 12.11 & 9.51 \\
\hline C. cajan & 4.50 & 7.18 & 5.74 & 7.99 & 7.63 & 4.44 & 12.18 & 9.22 \\
\hline $\operatorname{LSD}(0.05)$ & NS & NS & NS & NS & NS & NS & 3.79 & NS \\
\hline G. hirsutum + Z. mays & 4.98 & 4.40 & 8.23 & 7.92 & 6.84 & 3.85 & 8.41 & 8.22 \\
\hline O. sativa $+Z$. mays & 6.48 & 5.65 & 8.50 & 6.71 & 7.47 & 4.54 & 12.21 & 8.91 \\
\hline G. $\max +O \cdot$ sativa & 7.66 & 4.97 & 8.17 & 7.82 & 7.62 & 3.61 & 13.55 & 10.50 \\
\hline C. cajan $+O$. sativa & 4.91 & 5.90 & 9.97 & 6.90 & 9.48 & 3.72 & 11.50 & 8.62 \\
\hline$S$. indicum $+O$. sativa & 4.22 & 5.56 & 6.53 & 8.41 & 7.12 & 3.24 & 12.22 & 10.37 \\
\hline LSD $(0.05)$ & NS & NS & NS & NS & NS & NS & 3.38 & NS \\
\hline
\end{tabular}

hypothesis that there is a large variation in root biochemical composition among plant species grown under similar conditions, thereby having different decomposition rates. Roumet et al. ${ }^{16}$ reported that the root tissues of Fabaceae species are characterized by higher total $\mathrm{N}$ than those of Poaceae species.

\section{Dehydrogenase activity}

The DHA activity measured among different root biomasses and their combinations varied significantly at day 42 (Table 4). The highest DHA activity was observed in T4 treatment (G. max), reaching $14.35 \mu \mathrm{g}$ TPF g ${ }^{-1}$ soil h $^{-1}$, followed by $\mathrm{T} 2$ (Z. mays), T3 (G. max $+O$. sativa) and the lowest in treatment T0 (control). DHA is an important and one of the most sensitive bioindicators of soil fertility $^{17}$. The higher enzyme activity in T4, T2, T3 can be due to the release of enzymes from roots sustained by root exudates, or as a result of greater microbial activity $^{18}$. In compound treatments at day 42 , addition of $G$. max and $Z$. mays significantly increased DHA activity by $61.1 \%$ in treatment $\mathrm{T} 9$ and $45.2 \%$ in treatment $\mathrm{T} 8$ respectively, higher compared to treatment T0. Some studies demonstrated that root decomposition could vary among species depending on their biochemical composition (e.g. cellulose, hemicellulose, polysaccharides, polyphenols and soluble fractions) and microbial community structure $^{19,20}$. The results also showed greater enzymatic activity with high holocellulose (hemicellulose + cellulose) content (Figure 1).

In each treatment, DHA activity increased with the progression of incubation, but differences were found to be greater in the treatments having high holocellulose content, especially with root biomass of $G$. $\max$ and $Z$. mays (Figure 1 and Table 4). During the first seven days, the addition of different root biomasses alone or in combinations increased DHA activity from $5.74 \pm 0.09$ to
$10.36 \pm 0.03 \mu \mathrm{g} \mathrm{TPF} \mathrm{g}^{-1} \mathrm{~h}^{-1}$, compared to the control $\left(8.05 \pm 0.01 \mu \mathrm{g} \mathrm{TPF} \mathrm{g}^{-1} \mathrm{~h}^{-1}\right)$. However, after 28 days of incubation, significant increase in DHA activity (ranging from $11.50 \pm 0.01$ to $13.77 \pm 0.04 \mu \mathrm{g} \mathrm{TPF} \mathrm{g}^{-1} \mathrm{~h}^{-1}$ ) was observed compared to the control (reaching 7.59 \pm $0.04 \mu \mathrm{g}$ TPF $\mathrm{g}^{-1} \mathrm{~h}^{-1}$ ). A reasonable hypothesis could be that higher $\mathrm{C}: \mathrm{N}$ ratio of root biomass leads to slow decomposition rate and hence less DHA than in the control soils studied.

\section{Alkaline phosphatase activity}

The ALP activity from root biomass varied significantly among the treatments both in terms of species used and incubation time. The ALP activity among treatments showed significant increase on day 7 , ranging from $6.56 \pm 0.03$ to $9.20 \pm 0.02 \mu \mathrm{g}$ PNP g ${ }^{-1} \mathrm{~h}^{-1}$ over the control $\left(6.43 \pm 0.03 \mu \mathrm{g}\right.$ PNP $\left.\mathrm{g}^{-1} \mathrm{~h}^{-1}\right)$, suggesting increased availability of substrate in the soil. The results were found to be consistent with several studies on the increase in ALP activity with amendment of any organic matter ${ }^{21,22}$.

The ALP activity showed an increasing trend with the period of incubation throughout the experiment. With progression of the incubation period, the activity in treatment T3 was higher compared to the other treatments up to 63 days throughout the experiment. Among the different root biomasses and compound treatments, higher ALP activity was recorded in T3 (O. sativa), T9 ( $G$. $\max +O$. sativa) and $\mathrm{T} 10$ (C. cajan $+O$. sativa) with values $14.0 \pm 0.02,13.53 \pm 0.01$ and $13.51 \pm 0.01 \mu \mathrm{g}$ PNP $\mathrm{g}^{-1} \mathrm{~h}^{-1}$ at day 63 respectively, followed by T4, T6 and $\mathrm{T} 11\left(13.0,12.9\right.$ and $13.25 \mu \mathrm{g} \mathrm{PNP} \mathrm{g} \mathrm{g}^{-1} \mathrm{~h}^{-1}$ respectively). The lowest activity $\left(8.41 \mu \mathrm{g}\right.$ PNP g $\left.{ }^{-1} \mathrm{~h}^{-1}\right)$ was recorded in T0 (control). Higher activity of phosphatase enzyme in $O$. sativa (paddy biomass) might be due to the organic acids produced during decomposition, which in turn increased SOC and nitrogen ${ }^{23,24}$. Another reason for higher 
Table 5. Changes in alkaline phosphatase ( $\mu \mathrm{g}$ PNP $\left.\mathrm{g}^{-1} \mathrm{~h}^{-1}\right)$ activity among different root biomass treatments at various days of incubation

\begin{tabular}{lccccrrrr}
\hline & $1 \mathrm{st}$ & 3rd & 7th & 14 th & 21th & 28th & 42th & 63th \\
\hline Control & 4.00 & 5.33 & 6.43 & 8.46 & 6.60 & 7.52 & 5.01 & 8.41 \\
G. hirsutum & 4.68 & 5.75 & 6.71 & 9.65 & 9.22 & 9.84 & 6.66 & 11.6 \\
Z. mays & 4.71 & 5.59 & 7.66 & 10.7 & 10.78 & 10.69 & 8.25 & 12.7 \\
O. sativa & 4.47 & 7.00 & 7.73 & 11.0 & 12.68 & 11.41 & 9.18 & 14.0 \\
G. max & 4.46 & 5.07 & 6.56 & 9.71 & 12.20 & 9.81 & 7.86 & 13.0 \\
S. indicum & 3.76 & 5.31 & 6.76 & 8.98 & 9.92 & 10.46 & 6.08 & 12.8 \\
C. cajan & 3.00 & 6.58 & 7.57 & 10.9 & 11.66 & 10.78 & 8.11 & 12.9 \\
LSD $(0.05)$ & $\mathrm{NS}$ & $\mathrm{NS}$ & 0.94 & 1.54 & 2.30 & 1.05 & 1.95 & 2.93 \\
G. hirsutum + Z. mays & 3.52 & 6.17 & 7.44 & 10.0 & 9.44 & 10.37 & 6.40 & 10.37 \\
O. sativa + Z. mays & 3.90 & 5.99 & 7.34 & 10.3 & 11.51 & 12.25 & 7.51 & 12.16 \\
G. max + O. sativa & 4.34 & 6.14 & 7.91 & 10.3 & 10.05 & 13.67 & 8.78 & 13.53 \\
C. cajan + O. sativa & 4.21 & 6.67 & 9.20 & 11.5 & 10.68 & 12.19 & 10.12 & 13.51 \\
S. indicum + O. sativa & 3.69 & 6.50 & 7.78 & 11.5 & 9.53 & 12.10 & 8.63 & 13.25 \\
LSD $(0.05)$ & $\mathrm{NS}$ & $\mathrm{NS}$ & 1.03 & 1.31 & 2.20 & 2.39 & 2.02 & 1.69 \\
\hline
\end{tabular}

ALP activity at 63 days of incubation may be due to high amounts of microbial biomass produced during the decomposition of paddy straw by autochthonous microorganisms. ALP activity increases when there is equilibrated balance between added carbon and nitrogen ${ }^{25}$. Addition of organic manure to the soil leads to enhanced SOC status and microbial biomass, which subsequently enhances soil enzyme synthesis and accumulation. Increase in soil enzyme activity with the application of organic manure soil was reported by Goyal et al. ${ }^{26}$ and Dinesh et $a l .{ }^{27}$. In all the treatments, the mean enzymatic activity increased significantly from 7 to 63 days. The highest value of ALP was recorded at day 63 in all the treatments. There was significant decrease in enzyme activity from day 21 to day 28 , which may be due to temporal variations. This has also been reported by Nannipieri et $a .^{28}$, who confirmed that temporal variations in the activity of these enzymes were due to their differential production rates, as influenced by the physiological age of different groups of microorganisms present in the soil. The activity of alkaline phosphatase (APPA) is also an important biological indicator of soil fertility ${ }^{29,30}$. Like DHA, application of different types of root biomass positively influenced soil APPA. Maximum increase in APPA was observed up to 21 DAI in soil amended with different individual root biomasses, whereas it extended up to the 28 DAI under different combinations of root biomass. Among the root biomasses, rice and soybean showed highest increase (85-92\%) in APPA at 21 DAI, and their combination $(80 \%)$ at 28 DAI over control (Table 5). The possible reasons can be the synergistic effect of root residues in the mixture, which promote bacteria and fungi as they make available $P$ by secreting enzyme $A_{L P}{ }^{31}$. The organic $\mathrm{P}$ fraction in the soil organic matter is the main substrate for APPA to increase P supply in both natural and agricultural ecosystems. The inorganic fraction of soil $\mathrm{P}$ easily forms insoluble complexes with cations, and/or incorporated into organic matter by microbes $^{32,33}$.

\section{Basal soil respiration}

BSR, measured in terms of $\mathrm{CO}_{2}$ evolution and $\mathrm{O}_{2}$ consumption by the soil is frequently used for the determination of microbial activity in the soil. The rate of soil respiration was significantly affected by different root residues and their combinations (Table 6). Similar to DHA and APPA, highest respiration was observed in soil amended with maize followed by soybean among different root residues. Cumulative BSR in control was $176 \mathrm{mg}$ $\mathrm{CO}_{2}-\mathrm{C} \mathrm{g}^{-1}$ soil day ${ }^{-1}$, which increased to 492 and $486 \mathrm{mg}$ $\mathrm{CO}_{2}-\mathrm{C} \mathrm{g}^{-1}$ soil day ${ }^{-1}$ in maize and soybean respectively. Application of crop residues varying in biochemical composition would be expected to increase the soil biological activity and promote microorganisms due to increased $\mathrm{C}$ and $\mathrm{N}$ in the soil depending on the carbon source in the residue ${ }^{34,35}$. BSR as measured by $\mathrm{CO}_{2}$ production was related mainly to holocellulose content of different root residues. Both maize and soybean roots contained maximum cellulose content. Among different mixtures of root residues, highest BSR was observed in legumes-cereals than cereal-based combinations due to higher content of cellulose in legumes compared to cereal residues. BSR in residue amended soils was very low during initial days of incubation which could be due to the potential of the residue to overcome the obstinacy of the native microorganisms in the soil, because it usually acts as a buffer against soil inoculants ${ }^{36}$.

The present study showed the same pattern of decomposition of residues at varying rates, of which soybean and maize roots had high holocellulose content and showed greater enzymatic activity compared to the other root residues. Root biomasses from different plant species are known to differ in their cellulose and hemicellulose 
Table 6. Changes in cumulative soil respiration as influenced by root biomass of different species and their combinations

\begin{tabular}{lrrrrrr}
\hline & 7th & 14th & 21th & 28th & 42th & 63th \\
\hline Control & 111.8 & 126.0 & 138.1 & 148.3 & 165.6 & 172.8 \\
G. hirsutum - Z. mays & 286.9 & 349.3 & 384.3 & 421.0 & 453.8 & 478.6 \\
O. sativa - Z. mays & 307.1 & 367.6 & 400.6 & 436.7 & 469.2 & 500.1 \\
G. max-O. sativa & 297.0 & 355.7 & 395.0 & 431.9 & 463.0 & 491.3 \\
C. cajan-O. sativa & 324.5 & 384.5 & 424.4 & 464.4 & 502.1 & 529.4 \\
S. indicum-O. sativa & 283.3 & 336.4 & 375.2 & 412.6 & 445.6 & 470.1 \\
LSD (0.05) & 54.0 & 51.3 & 51.3 & 51.4 & 52.5 & 55.7 \\
G. hirsutum-Z. mays & 286.9 & 349.3 & 384.3 & 421.0 & 453.8 & 478.6 \\
O. sativa - Z. mays & 307.1 & 367.6 & 400.6 & 436.7 & 469.2 & 500.1 \\
G. max-O. sativa & 297.0 & 355.7 & 395.0 & 431.9 & 463.0 & 491.3 \\
C. cajan-O. sativa & 324.5 & 384.5 & 424.4 & 464.4 & 502.1 & 529.4 \\
S. indicum-O. sativa & 283.3 & 336.4 & 375.2 & 412.6 & 445.6 & 470.1 \\
LSD (0.05) & 51.4 & 50.9 & 51.0 & 50.5 & 51.5 & 52.5 \\
\hline
\end{tabular}

Table 7. Changes in cumulative organic carbon content as influenced by root biomass of different species and their combinations

\begin{tabular}{|c|c|c|c|c|c|c|c|c|}
\hline & $1 \mathrm{st}$ & $3 \mathrm{rd}$ & 7 th & 14th & 21 th & 28 th & 42 th & 63 th \\
\hline & & & & 0.48 & & 0.43 & & 0.50 \\
\hline Control & 0.535 & 0.508 & 0.534 & 8 & 0.506 & 6 & 0.534 & 8 \\
\hline \multirow[t]{3}{*}{ G. hirsutum } & 0.833 & 0.724 & 0.773 & 0.69 & 0.660 & 0.56 & 0.714 & 0.68 \\
\hline & & & & 4 & & 0 & & 4 \\
\hline & & & & 0.84 & & 0.80 & & 0.86 \\
\hline \multirow{2}{*}{ Z. mays } & 0.958 & 0.861 & 0.920 & 2 & 0.850 & 6 & 0.848 & 8 \\
\hline & & & & 0.72 & & 0.61 & & 0.70 \\
\hline \multirow[t]{2}{*}{ O. sativa } & 0.883 & 0.855 & 0.701 & 1 & 0.732 & 6 & 0.724 & 7 \\
\hline & & & & 0.72 & & 0.64 & & 0.74 \\
\hline \multirow[t]{2}{*}{ G. $\max$} & 0.886 & 0.855 & 0.838 & 7 & 0.739 & 8 & 0.743 & 0 \\
\hline & & & & 0.72 & & 0.65 & & 0.74 \\
\hline \multirow[t]{2}{*}{ S. indicum } & 0.925 & 0.888 & 0.845 & 4 & 0.768 & 8 & 0.793 & 7 \\
\hline & & & & 0.77 & & 0.69 & & 0.79 \\
\hline \multirow[t]{2}{*}{ C. cajan } & 0.938 & 0.960 & 0.907 & 0 & 0.791 & 4 & 0.796 & 6 \\
\hline & & & & 0.04 & & 0.11 & & 0.05 \\
\hline $\operatorname{LSD}(0.05)$ & 0.069 & 0.093 & 0.074 & 2 & 0.054 & 0 & 0.083 & 4 \\
\hline \multirow[t]{3}{*}{ G. hirsutum - Z. mays } & & & & 0.72 & & 0.66 & & 0.71 \\
\hline & 0.824 & 0.812 & 0.770 & 4 & 0.676 & 5 & 0.743 & 7 \\
\hline & & & & 0.79 & & 0.72 & & 0.71 \\
\hline \multirow[t]{2}{*}{ O. sativa $-Z$. mays } & 0.945 & 0.858 & 0.861 & 3 & 0.804 & 4 & 0.799 & 1 \\
\hline & & & & 0.69 & & 0.63 & & 0.71 \\
\hline \multirow[t]{2}{*}{ G. $\max -O$. sativa } & 0.853 & 0.786 & 0.832 & 1 & 0.699 & 2 & 0.724 & 7 \\
\hline & & & & 0.70 & & 0.67 & & 0.69 \\
\hline \multirow{4}{*}{$\begin{array}{l}\text { C. cajan }-O \text {. sativa } \\
\text { S. indicum - O. sativa }\end{array}$} & 0.919 & 0.770 & 0.891 & 1 & 0.755 & 8 & 0.737 & 4 \\
\hline & & & & 0.75 & & 0.68 & & 0.76 \\
\hline & 0.876 & 0.809 & 0.809 & 7 & 0.699 & 1 & 0.773 & 3 \\
\hline & & & & 0.04 & & 0.06 & & 0.07 \\
\hline LSD (0.05) & 0.081 & 0.071 & 0.068 & 7 & 0.046 & 7 & 0.037 & 2 \\
\hline
\end{tabular}

content, which in turn will affect the decomposition rate depending on the availability of $\mathrm{C}$ and $\mathrm{N}^{37}$. Among different root biomasses, maize, soybean and maizesoybean combination treatments showed significantly higher DHA compared to other root biomass and their combinations. DHA at 42 DAI significantly increased by $81.4 \%, 89.1 \%$ and $78.5 \%$ in maize, soybean and their combination respectively, compared to control.

\section{Organic carbon}

In the soil system, $\mathrm{OC}$ is mainly contributed by root decomposition and crop residue incorporation ${ }^{38}$. Biotic interactions in the biochemically different root biomasses have a profound effect on SOC content. Over the incubation period from 7 to 42 days, OC content showed increasing trend $(0.701 \%$ to $0.920 \%)$ compared to control 
Table 8. Pearson's correlation coefficient among the observed parameters

\begin{tabular}{|c|c|c|c|c|c|c|c|c|}
\hline \multirow[b]{2}{*}{ Parameters } & \multicolumn{4}{|c|}{ Root biomass of different species } & \multicolumn{4}{|c|}{ Root biomass of compound treatment system } \\
\hline & DHA & APPA & BSR & $\mathrm{OC}$ & DHA & APPA & BSR & $\mathrm{OC}$ \\
\hline DHA & 1 & $0.759 *$ & $0.861 *$ & $0.849 *$ & 1 & $0.803 * *$ & 0.698 & 0.675 \\
\hline APPA & & 1 & $0.819 *$ & 0.622 & & 1 & $0.786 * *$ & 0.636 \\
\hline
\end{tabular}

DHA, Dehydrogenase; APPA, Alkaline phosphatase; BSR, Basal soil respiration; OC, Organic carbon. $* P<0.01 ; * * P<0.05$.

$(0.534 \%)$. The change in OC content during incubation study was found to be higher in maize followed by pigeon pea and least in the soil amended with cotton root biomass, whereas in their combinations, highest change in $\mathrm{OC}$ content was in rice-maize followed by sesame-rice and least in soybean-rice incorporated soils (Table 7). The increase in OC content in residue-treated soils can be attributed to the stimulation of growth and activity of microorganisms, resulting in higher production of microbial biomass ${ }^{39,40}$. Higher organic content during the decomposition of different root residues in the present study can be related to specific types of rhizodeposits and plant residues, and therefore can affect carbon content in the soil ${ }^{41,42}$.

\section{Correlation of enzyme activities with soil respiration and soil organic carbon content}

Both DHA and APPA assayed in the study were significantly and positively correlated with OC and BSR (Table $8)$. The values of correlation coefficient $(r)$ for soil enzyme activities ranged from $0.759 *$ to $0.938 * *$. Significant correlations between enzyme activity and $\mathrm{OC}$ observed in this study suggest a general relationship between soil microbiological properties. Accumulation of root biomass improved the OC status of soils, which in turn was reflected in higher soil enzymatic activity ${ }^{43,44}$. It is evident that soil enzymatic activity is strongly correlated with SOC content. The higher OC level can provide enough substrate to support higher microbial activity and hence higher enzyme production ${ }^{45}$.

\section{Conclusion}

Soil enzymes activity is sensitive to changes occurring in soil processes due to addition of root biomass having different biochemical composition. Addition of different root biomasses increased soil microbial activity over unamended control. The present study suggests that decomposition of root biomass can be controlled by labile compound present in biochemically different mixtures of root biomass by a broad range of biochemical composition and chemical heterogeneity of the mixtures. Holocellulose content in different root residues was the sole factor that explained the large variability in Cmineralization and enzymes activity in amended soil.

1. Cadish, G. and Giller, K. E., Driven by Nature: Plant Residue, Quality and Decomposition, CAB International, Wallingford, UK. 1997, p. 409.

2. Stemmer, C., Grimm, R. and Grasser, K. D., Occurrence of five different chromosomal HMG1 proteins in various maize tissues. Plant Mol. Biol., 1999, 41, 351-361.

3. Svensson, K. and Pell, M., Soil microbial tests for discriminating between different cropping systems and fertilizer regimes. Biol. Fertil. Soils, 2001, 33, 91-99.

4. Zhang, D., Hui, D., Luo, Y. and Zhou, G., Rates of litter decomposition in terrestrial ecosystems: global patterns and controlling factors. J. Plant Ecol., 2008, 1, 85-93.

5. DeAngelis, K. M., Lindow, S. E. and Firestone, M. K., Bacterial quorum sensing and nitrogen cycling in rhizosphere soil. FEMS Microbiol. Ecol., 2008, 66, 197-207.

6. Gessner, M. O., Swan, C. M., Dang, C. K., McKie, B. G., Bardgett, R. D., Wall, D. H. and Hättenschwiler, S., Diversity meets decomposition. Trends Ecol. Evol., 2010, 25, 372-380.

7. Phillips, R. P., Finzi, A. C. and Bernhardt, E. S., Enhanced root exudation induces microbial feedbacks to $\mathrm{N}$ cycling in a pine forest under long-term $\mathrm{CO}_{2}$ fumigation. Ecol. Lett., 2011, 14, 187194.

8. Baum, C., Leinweber, P. and Schlichting, A., Effects of chemical conditions in re-wetted peats temporal variation in microbial biomass and acid phosphatase activity within the growing season. Appl. Soil Ecol., 2003, 22, 167-174.

9. Sinsabaugh, R. L. et al., Stoichiometry of soil enzyme activity at global scale. Ecol. Lett., 2008, 11, 1252-1264.

10. Baldrian, P. et al., Active and total microbial communities in forest soil are largely different and highly stratified during decomposition. ISME J., 2012, 6(2), 248-258.

11. Van Soest, P. J., Use of detergents in the analysis of fibrous feeds. II. A rapid method for the determination of fiber and lignin. $J$. Assoc. Off. Anal. Chem., 1963, 46, 829-835.

12. Camiña, F., Trasar-Cepeda, C., Gil-Sotres, F. and Leirós, C., Measurement of dehydrogenase activity in acid soils rich in organic matter. Soil Biol. Biochem., 1998, 30, 1005-1011.

13. Tabatabai, M. A. and Bremner, J. M., Use of $p$-nitrophenyl phosphate for assay of soil phosphatase activity. Soil Biol. Biochem., 1969, 1, 301-307.

14. Alef, K., Basal respiration. In Method in Applied Soil Microbiology and Biochemistry (eds Alef, K. and Nannipieri, P.), Academic Press: Harcourt Brace Company, London, UK, 1995, pp. 228-231.

15. Walkley, A. and Black, I. A., An examination of Degtjareff method for determining soil organic matter and a proposed modification of the chromic acid titration method. Soil Sci., 1934, 37, 29-37.

16. Roumet, C., Lafont, F., Sari, M., Warembourg, F. and Garnier, E., Root traits and taxonomic affiliation of nine herbaceous species grown in glasshouse conditions. Plant Soil, 2008, 312, 69-83. 
17. Wolinska, A. and Stepniewska, Z., Dehydrogenase activity in the soil environment. In Dehydrogenases (ed. Canuto, R. A.), Intech, Rijeka, 2012.

18. Villányi, I., Füzy, A. and Biró, B., Non-target microorganisms affected in the rhizosphere of transgenic Bt corn. Cereal Res. Commun., 2006, 34, 105-109.

19. Goh, K. M. and Tutuna, S. S., Effects of organic and plant residue quality and orchard management practices on decomposition rates of residues. Commun. Soil Sci. Plant Anal., 2004, 35, 441-460.

20. Hadas, A., Kautsky, L., Goek, M. and Kara, E. E., Rates of decomposition of plant residues and available nitrogen in soil, related to residue composition through simulation of carbon and nitrogen turnover. Soil Biol. Biochem., 2004, 36, 255-266.

21. Jordan, D., Kremer, R. J., Bergfield, W. A., Kim, K. Y. and Cacnio, V. N., Evaluation of microbial methods as potential indicators of soil quality in historical agricultural fields. Biol. Fert. Soils, 1995, 19, 297-302.

22. Kremer, R. J. and Li, J., Developing weed-suppressive soils through improved soil quality management. Soil Till. Res., 2003, 72, 193-202.

23. Kadlag, A. D., Jadav, A. B. and Kale, Y. B., Urease and acid phosphatase soil enzymes are influenced by vermicompost and scepter herbicide. J. Maharashtra Agric. Univ., 2008, 33(2), 148151.

24. Srilatha, M., Rao, P. C., Sharma, S. H. K. and Bhanu, R., Influence of long term fertilizer application on soil phosphatase enzyme activity and nutrient availability in rice-rice cropping system. J. Rice Res., 2013, 2, 45-54.

25. Nanipierri, P., The potential use of soil enzymes as indicator of productivity, sustainability and pollution. In Soil Biota, Management in Sustainable Farming System (eds Pankhurst, C. E. et al.), CSIRO, Melbourne, Australia, 1994, pp. 218-244.

26. Goyal, S., Mishra, M. M., Dhankar, S. S., Kapoor, K. K. and Batra, R., Microbial biomass turnover and enzyme activities following the application of farmyard manure to field soils with and without previous long-term applications. Biol. Fertil. Soils, 1993, 15, 60-64

27. Dinesh, R., Dubey, R. P., Ganeshamurthy, A. N. and Shyam Prasad, G., Organic manuring in rice-based cropping system: effects on soil microbial biomass and selected enzyme activities. Curr. Sci., 2000, 79(12), 1716-1720.

28. Nannipieri, P., Pedrazzini, P., Arcara, P. G. and Piovanelli, C., Changes in amino acids, enzyme activities and biomasses during soil microbial growth. Soil Sci., 1979, 127, 26-34.

29. Dodor, D. E. and Tabatabai, M. A., Effect of cropping systems on phosphatases in soils. J. Plant Nutr. Soil Sci., 2003, 166, 7-13.

30. Nannipieri, P., Giagnoni, L., Landi, L. and Renella, G., Role of phosphatase enzymes in soil. In Phosphorus in Action: Biological Processes in Soil Phosphorus Cycling (eds Bunemann, E., Oberson, A. and Frossard, E.), Springer, Heidelberg, Germany, 2011, pp. 251-244.

31. Hebrien, S. A. and Neal, J. L., Soil pH and phosphatase activity. Commun. Soil Sci. Plant Anal., 1990, 21, 489-456.

32. Vance, C. P., Uhde-Stone, C. and Allan, D. L., Phosphorus acquisition and use: critical adaptations by plants for securing a nonrenewable resource. New Phytol., 2003, 157, 423-447.
33. Tran, H. T., Hurley, B. A. and Plaxton, W. C., Feeding hungry plants: the role of purple acid phosphatases in phosphate nutrition. Plant Sci., 2010, 179(1), 14-27.

34. Peacock, A. D., Mullen, M. D., Ringelberg, D. B., Tyler, D. D., Hedrick, D. B., Gale, P. M. and White, D. C., Soil microbial community responses to dairy manure or ammonium nitrate applications. Soil Biol. Biochem., 2001, 33, 1011-1019.

35. Stark, C., Condron, L. M., Stewart, A., Di, H. J. and O'Callaghan, $\mathrm{M}$., Influence of organic and mineral amendments on soil microbial properties and processes. Appl. Soil Ecol., 2007, 35, 79-93.

36. van Veen, J. A., van Overbeek, L. S. and van Elsas, J. D., Fate and activity of microorganisms introduced into soil. Microbiol. Mol. Biol. Rev., 1997, 61, 121-135.

37. Nicolardot, B., Recous, S. and Mary, B., Simulation of C and N mineralisation during crop residue decomposition: a simple dynamic model based on the $\mathrm{C}: \mathrm{N}$ ratio of the residues. Plant Soil, 2001, 228, 83-103.

38. Gale, W. J. and Camberdella, C. A., Carbon dynamics of surface residue-and root- derived organic matter under simulated no-till. Soil Sci. Soc. Am. J., 2000, 64, 190-195.

39. Rudrappa, L., Purakayastha, T. J., Singh, D. and Bhadraray, S., Long-term manuring and fertilizer effects on soil organic carbon pools in a Typic Haplustept of semi-arid sub-tropical India. Soil Till. Res., 2006, 88, 180-192.

40. Moharana, P. C., Sharma, B. M., Biswas, D. R., Dwivedi, B. S. and Singh, R. V., Long term effect of nutrient management on soil fertility and soil organic carbon pools under a 6-year-old pearl millet-wheat cropping system in an Inceptisol of subtropical India. Field Crops Res., 2012, 136, 32-41.

41. Chantigny, M. H., Prévost, D., Angers, D. A., Vézina, L. P. and Chalifour, F. P., Microbial biomass and $\mathrm{N}$ transformations in two soils cropped with annual and perennial species. Biol. Fertil. Soils, 1996, 21, 239-244.

42. Mahmood, T., Kaiser, W., Ali, R., Ashraf, M., Gulnaz, A. and Iqbal, Z., Ammonium and nitrate nutrition of plants stimulates microbial activity in the rhizosphere. Plant Soil, 2005, 277, 233243.

43. Omidi, H., Tahmasebi, Z., Torobi, H. and Miransari, M., Soil enzymatic activities and available $\mathrm{P}$ and $\mathrm{Zn}$ as affected by tillage practices, canola (Brassica napus L.) cultivars and planting dates. Eur. J. Soil Biol., 2008, 44, 443-450.

44. Gajda, A. M., Przewłoka, B. and Gawryjołek, K., Changes in soil quality associated with tillage system applied. Int. Agrophys., 2013, 27, 133-141.

45. Yuan, B. C. and Yue, D. X., Soil microbial and enzymatic activities across a chronosequence of Chinese pine plantation development on the loess plateau of China. Pedosphere, 2012, 22, $1-12$.

Received 10 June 2019; revised accepted 10 September 2020

doi: $10.18520 / \mathrm{cs} / \mathrm{v} 119 / \mathrm{i} 11 / 1807-1814$ 